\title{
Territorial Trends in the Spatial Development of Industries and Enterprises
}

\author{
Alexey Shinkevich \\ Kazan National Research Technological University \\ Kazan, Russia \\ ashinkevich@mail.ru \\ Regina Yakunina \\ Kazan National Research Technological University \\ Kazan, Russia \\ ya.rp@list.ru
}

\author{
Olga Minulina \\ Kazan National Research Technological University \\ Kazan, Russia \\ ashinkevich@mail.ru \\ Elena Dolonina \\ Kazan National Research Technological University \\ Kazan, Russia \\ ashinkevich@mail.ru
}

\begin{abstract}
The article describes the trends in the spatial development of industries based on the concept of human capital. The article is also devoted to identifying the features of the concept of "spatial development". The work used general scientific methods of theoretical and empirical knowledge: the causal method, the statistical method, the method of analysis and synthesis, the method of scientific abstraction. The article goes on to say that there are twelve macro-regions of Russia are identified in the Strategy for the spatial development of the regions of the Russian Federation until 2025. The article discusses the goal, objectives and principles of the Spatial Development Strategy of Russia. Based on the macro-regions of the Russian Federation, an author's methodology for calculating the human development index is proposed, the new components of which are the unemployment rate and wages. The dynamics of the human development index is analysed using the example of Russian macro-regions. Macro-regions are identified as leaders and lagging macro-regions that require an increase in the level of human capital. The main purpose of our article is to study and analyze territorial trends in spatial development based on human capital. The findings of the study can serve as a basis for the formation of a scientifically based methodology for strategic planning in terms of spatial development.
\end{abstract}

Keywords-spatial development, spatial development of industries, spatial development strategy, human capital, human development index, macro-region, strategic planning, territorial development, spatial planning, territorial planning.

\section{INTRODUCTION}

The paper focuses the reader's attention on the trends of the Strategy for spatial development of the Russian Federation regions based on the human capital concept and theory. The adopted Federal Law No. 172-FZ of June 28, 2014 "On Strategic Planning in the Russian Federation" is the main fundamental factor that is used in the Russian strategic planning system. So, according to the order of the Government of the Russian Federation dated February 13, 2019 No. 207-r, the Strategy for the spatial development of the Russian Federation for the period up to 2025 was approved. This strategy is one of the most important innovations in strategic planning documents. The strategy is a kind of territorial projection of the socio-economic development strategy [1]. There are some objectives of the Strategy for spatial development, such as an ensuring sustainable and balanced spatial development of Russia, accelerating economic growth and technological development, reducing interregional differences in people's living standards and ensuring national security. The strategy sets the goal, objectives and priorities for the spatial development of Russia. It also determines its main directions, promising centers of economic growth, priority scenarios for spatial development, macro-regions and target indicators of the spatial development of Russia [2].

Based on the tasks on the solution of which the Spatial Development Strategy should be focused, in its Concept:

- the place and role of the Spatial Development Strategy in the strategic planning system of the Russian Federation

- identified the main challenges to the spatial development of Russia in the forecast period;

- on the basis of a comprehensive analysis of the modern spatial organization of Russia, the main imbalances in its spatial development are determined;

- identified the main factors, conditions, problems and risks spatial development of the country for the future;

- proposed conceptual approaches to the formation of a vision of the spatial development of Russia for the long term [13].

Also, in the Strategy 12 macro-regions were formed. The list of promising centers of economic growth includes promising cities that form large urban agglomerations and largest urban agglomerations, which will contribute more than $1 \%$ to economic growth annually ( 20 centers); promising centers of economic growth of the subjects of the Federation, which will provide a contribution to economic growth from $0.2 \%$ to $1 \%$ annually (44 centers); promising centers of economic growth of the constituent entities of the Federation, which will provide a contribution to economic growth of up to $0.2 \%$ annually (31 centers); promising mineral resources and agro-industrial centers ( 27 centers); promising centers of 
economic growth, in which conditions have developed for the formation of world-class scientific and educational centers (20 centers) [2].

Consequently, the main purpose of our article is to examine territorial trends in spatial development based on human capital. Achieving the stated goal requires solving a set of tasks:

- to assess the condition of the capital of the macroregions of the Russian Federation;

- to assess the capital of Russian macro regions based on the modernized human development index; - compile and consider the dynamics of human development in the macro regions of Russia.

To assess the state of human capital in the macro regions of the Russian Federation, first of all, let us turn to the Strategy for the Spatial Development of the Russian Federation for the Period up to 2025 (hereinafter referred to as the Strategy), approved by the Order of the Government of the Russian Federation dated February 13, 2019 No. 207-r [1], which aims to reduce interregional differences in the level and quality of life of the population, acceleration of economic growth, as well as ensuring sustainable and balanced spatial development of Russian regions [4].

\section{METHODS}

In order to reduce the level of interregional differences in the social and economic development of Russian regions, the Spatial Development Strategy provides for the following [7]:

- improving the quality of transport infrastructure;

- increasing the availability of telecommunications infrastructure;

- improving the quality of information infrastructure;

- increasing the availability of the main energy infrastructure.

In order to form the main conceptual provisions of the Spatial Development Strategy, the term spatial development is proposed to mean progressive changes in the spatial (territorial) organization of society. These progressive changes should be the result of the state's purposeful activities to improve the organization of resettlement of residents, the placement of economic, social, transport, energy and other infrastructures, etc [1].

\section{MAIN PART}

\section{RELATED WORK}

We have divided the existing work into two categories. The first is literature review and the second is the methodology of Spatial Development Strategy.

\section{LITERATURE REVIEW}

The study and analysis of the specifics of spatial development cannot be imagined without taking into account the specifics of the economic space. Researchers wrote about the problems of its formation and further transformation in the 18th century. A. Smith, who created the concept of absolute advantages, and D. Ricardo, who proposed the theory of comparative advantages, are considered the founders of the science of the spatial organization of the economy [12].
Research in the field of spatial development in our country is still at the initial stage of study and development. A single and basic concept of a spatial development management system has not yet been established. Also, common goals, objectives, problems and methods of spatial development are not defined. Among the most famous Russian researchers conducting their research in the field of spatial economics, one can single out such as A.G. Granberg, V. Knyaginin, Yu. Perelygin, S.A. Suspitsyn, P.A. Minakir, I.T. Nasretdinov, V.N. Leksin and V.I. Suslov, A.N. Bufetova [14].

To begin with, we will try to give a definition of spatial development and what different researchers mean by it. V. Knyaginin and Yu. Perelygin see the key meaning of spatial development in a set of measures to harmonize multidirectional processes on the territory and optimize the ongoing changes [3]. Under the spatial transformations of the economy, Suspitsyn S.A. understands the process of changing the long-term stable indicators of the development of the multi-regional economic system of Russia, cleared of national trends.

There are a lot of different work in foreign experience such as "Accessibility and Spatial Development in Europe" by Klaus Spiekermann and Michael Wegener who analyze an analysis of the current spatial distribution of accessibility indicators across Europe [16].

Eduardo Medeiros debates about spatial planning or territorial planning, describes their possibilities and advantages of using territorial impact assessment policy evaluation methodologies to assess the implementation of spatial planning instruments [15].

Klaus Desmet and Esteban Rossi-Hansberg in the article "Spatial Development" have presented a theory of spatial development. Manufacturing and services firms located in a continuous geographic area choose each period how much to innovate. Firms trade subject to transport costs and technology diffuses spatially [12].

Regional and spatial aspects relating to the demand for, and the supply of, finance for small and medium-sized enterprises and start-ups is associated with the names of Elisa Ughetto, Marc Cowling \&Neil Lee [11].

Many economists have dealt with the problem of human capital research, but such theoretical economists as $\mathrm{M}$. Friedman, L. Thurow, T. Stounier, M. Blaug made a significant contribution to the disclosure of the essence of human capital. The development of the theory of human capital in the late 19th - early 20th centuries is associated with the names of L. Walras, J.M. Clark, F. List, J. McCulloch, G. D. MacLeod, A. Marshall, J. S. Mill, S. Say, I. Fisher, S. Walsh, I.F. Thünen and others [5].

Currently, the most significant works and publications devoted to the formation and use of human capital in Russia include the works of V.E. Aperyan, I.N. Belogrud, V.M. Galperin, V.D. Dorofeeva, V.M. Kolesova, Yu.A. Korchagina, R.M. Nureyev, O. I. Opaleva, L.G. Simkina, I.V. Skoblyakova, V.T. Smirnova, A.A. Tsyrenova, E.D. Tsyrenova, E.L. Shemyakin, G.Kh. Shingarova, Ya.S. Yadgarova. The classification of types of human capital in the knowledge economy was considered by A.A. Gafurova, V. Yu. Konyukhov, R. Yu. Lagerev, M.V. Potnova, K. A. Schneider [6]. 
Of particular interest are the modern annual Human Development Reports, which describe how human capital is measured using the Human Development Index, which are compiled by the United Nations Development Program, and the Global Human Capital Report, developed by representatives of the World Economic Forum.

\section{METHODOLOGY}

In order to reduce the level of interregional differences in the social and economic development of Russian regions, the Spatial Development Strategy provides for the following [7]:

- improving the quality of transport infrastructure;

- increasing the availability of telecommunications infrastructure;

- improving the quality of information infrastructure;

- increasing the availability of the main energy infrastructure.

In order to form the main conceptual provisions of the Spatial Development Strategy, the term spatial development is proposed to mean progressive changes in the spatial (territorial) organization of society. These progressive changes should be the result of the state's purposeful activities to improve the organization of resettlement of residents, the placement of economic, social, transport, energy and other infrastructures, etc [1].

Achieving the goal of reducing differences in the living standards of people between regions of Russia is also important as a means of improving and increasing human capital in regional socio-economic systems. To determine the ways of solving the problem, a complete understanding of the state of human capital in the country and specifically in each constituent entity of the Russian Federation is required [8].

Our research is aimed at forming an idea of the level and quality of life of the population in the macro regions of the Russian Federation within the framework of the formation and use of human capital and its social characteristics. Consequently, this article presents new results that develop the direction of socio-economic research, which are obtained using a modernized index approach to assessing human capital.

According to the Spatial Development Strategy, 12 macro-regions have been formed: Central, Central Black Earth, Northwest, North, South, North Caucasian, VolgaKama, Volga-Ural, Ural-Siberian, South Siberian, AngaraYenisei, Far East. The full composition of the macro-regions according to the Strategy are presented in Table 1.

TABLE I. COMPOSITION OF MACRO REGIONS OF THE RUSSIAN FEDERATION

\begin{tabular}{|c|c|c|}
\hline & Macro-region & Macro-region composition \\
\hline 1 & Central & $\begin{array}{l}\text { Bryansk region, Vladimir region, Ivanovo region, Kaluga region, Kostroma region, Moscow region, } \\
\text { Oryol, Ryazan, Smolensk and Tver regions, Tula and Yaroslavl regions, Moscow }\end{array}$ \\
\hline 2 & Central Black Earth & Belgorod region, Voronezh region, Kursk region, Lipetsk and Tambov regions \\
\hline 3 & Northwestern & $\begin{array}{l}\text { Republic of Karelia, Kaliningrad, Vologda region, Leningrad region, Murmansk, Novgorod and Pskov } \\
\text { regions, Saint Petersburg }\end{array}$ \\
\hline 4 & Northern & Komi Republic, Arkhangelsk Region, Nenets Autonomous District \\
\hline 5 & Southern & $\begin{array}{l}\text { Republic of Adygea, Republic of Kalmykia, Republic of Crimea, Krasnodar Territory, Astrakhan } \\
\text { region, Volgograd and Rostov Regions, Sevastopol }\end{array}$ \\
\hline 6 & North Caucasian & $\begin{array}{l}\text { Republic of Dagestan, Ingushetia, North Ossetia - Alania, Kabardino-Balkarian, Karachay-Cherkess } \\
\text { and Chechen Republics, Stavropol Region }\end{array}$ \\
\hline 7 & Volgo-Kamsky & $\begin{array}{l}\text { Republic of Mari El, Mordovia, Republic of Tatarstan, Udmurt and Chuvash republics, Perm, Kirov } \\
\text { and Nizhny Novgorod regions }\end{array}$ \\
\hline 8 & Volgo-Uralsky & $\begin{array}{l}\text { Republic of Bashkortostan, Orenburg region, Penza region, Samara region, Saratov and Ulyanovsk } \\
\text { regions }\end{array}$ \\
\hline 9 & Ural-Siberian & $\begin{array}{l}\text { Kurgan, Sverdlovsk, Tyumen and Chelyabinsk regions, Khanty-Mansiysk Autonomous Okrug - Yugra, } \\
\text { Yamalo-Nenets Autonomous Okrug }\end{array}$ \\
\hline 10 & South Siberian & Altai Republic, Altai Region, Kemerovo region, Novosibirsk, Omsk and Tomsk region \\
\hline 11 & Angara-Yenisei & Republic of Tuva, Khakassia, Krasnoyarsk and Irkutsk Region \\
\hline 12 & Far Eastern & $\begin{array}{l}\text { Republics of Buryatia, Sakha (Yakutia), Zabaikalsky, Kamchatsky, Primorsky and Khabarovsk } \\
\text { Territories, Amur region, Magadan region, Sakhalin Regions, Jewish Autonomous Region, Chukotka } \\
\text { Autonomous District }\end{array}$ \\
\hline
\end{tabular}

Within the framework of this study, in the 12 macroregions presented, the results of assessing human capital were tested on the basis of a modernized human development index, which includes indicators of education level, unemployment rate, wage level and average life expectancy of the population. For completeness of data reliability, the subjects of the Russian Federation included in the macroregion were selected according to the criterion of the availability of statistical data published by the Russian statistics service for the analyzed period from 2010 to 2017 [10]. The sample does not include the federal city of Sevastopol and the Republic of Crimea as subjects of the Russian Federation, since they became part of Russia in 2014. The data provided up to 2014 takes into account the development index of the Republic of Crimea and the city of Sevastopol when they were part of Ukraine. Also not included in the sample are the Nenets Autonomous Okrug, the Yamalo-Nenets Autonomous Okrug, and the KhantyMansi Autonomous Okrug - Yugra. These regions are not included in the sample due to the lack of statistical data on some indicators that are necessary for calculating the human development index in order to assess the level of human capital in the macro-regions of the Russian Federation.

In our study, we used the Human Development Index. The Human Development Index is a composite indicator of human development in countries and regions of the world, produced by the United Nations Development Program (UNDP) and used in a special series of human development reports [5]. We know that The Human Development Index is a comprehensive indicator of a person's standard of living in a particular country, therefore it is sometimes used as a 
synonym for concepts such as "quality of life" or "standard of living". The index measures a country's achievements in terms of health status, education and actual income of its citizens, in three main areas for which their indices are assessed:

- Life Expectancy Index: Health and longevity, measured by the average life expectancy at birth.

- Education Index: Access to education as measured by the average expected length of schooling for school-age children and the average length of schooling for the adult population.
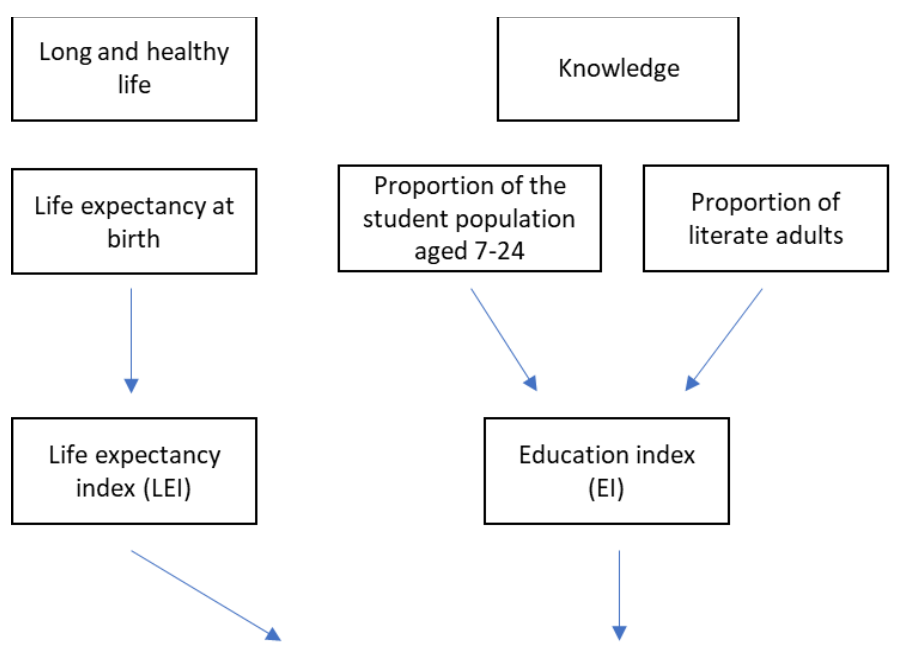

\section{Human development index (HDI)}

- Gross National Income Index: A decent standard of living as measured by gross national income (GNI) per capita in US dollars at purchasing power parity (PPP).

In our article, we will use the methodology for calculating the human development index among the macro-regions of the Russian Federation, developed by the authors of this study. To assess human capital among the macro-regions of the Russian Federation, the following components of the human development index were considered: life expectancy at birth (number of years), literacy rate of the adult population (percentage), the proportion of the student population aged 7 to 24 , as well as the unemployment rate and real wages of the population, taking into account the size of the subsistence minimum instead of the level of income (Fig.1).

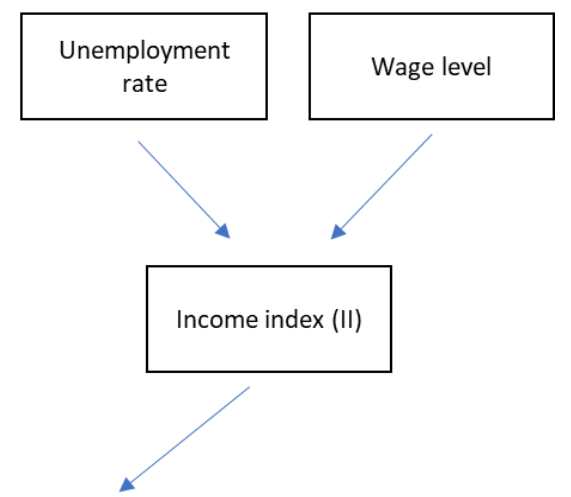

Fig.1. Human Development Index structure developed by the authors

Based on the purpose of our research, we propose to use an index approach that is able to identify the strengths, weaknesses, and problems of each macro-region. Our local index is formed of two indicators, which allows us to quantify the macro-region. And based on this, we will give recommendations on the main directions of development of macro-regions in Russia, as well as on the main mechanisms of human capital management in the sectors of the Russian economy.

However, the analysis of the human development index and the mechanism for the formation of its components gives rise to doubts about the success of the conceived, firstly, because the human development index of macro-regions was not previously calculated, and secondly, the statistical data separately for each of the twelve macro-regions (for example, for the Federal Districts statistical data are available similarly to regional ones) are not yet published by the statistics service due to the very recent approval of the Strategy. In this regard, we independently calculated the human development index of macro-regions.

\section{OUR CONTRIBUTION}

In our research work, we have also developed and implemented a method for assessing human capital using the human development index by adding new components to the standard approach. The standard method for calculating the human development index assumes its measurement as a geometric mean of three sub-indices: education index, longevity index and income index. We proposed and developed the inclusion of new components in the final calculation formula - the wage index and the unemployment index, which, in our opinion, more fully and accurately reflect the situation in the country and assess the level of human development of an individual.

The analysis of the methodology allowed the authors to rank the regions according to the human development index, identify the leading regions regardless of the methodology used, and this comparative analysis makes it possible to observe the dynamics of the situation in the regions under consideration due to the inclusion of the wage index and the unemployment index in the formula for calculating the human development index. After that, we calculated the human development index among the macro-regions of the Russian Federation and analyzed the dynamics of these regions [9].

\section{BACKGROUND}

Data. To calculate the human development index of macro-regions, we used the HDI calculated by us earlier for the regions of the Russian Federation, weighted by the population for the regions of the Russian Federation. Thus, the formula for calculating the human development index of macro-regions is as follows: 


$$
H D I_{\text {macro } i}=\frac{\sum\left(\text { HDI }_{\text {region } i} * \text { Population }_{\text {region } i}\right)}{\sum\left(\text { Population }_{\text {region } i}\right)},
$$

where $H D I_{\text {macro } i}$ - human development index of the i-th macro-region;

region $i$ - region of the Russian Federation included in the macro-region;

macro $i$ - макрорегион Российской Федерации.
Despite the fact that the Spatial Development Strategy of the Russian Federation for the period up to 2025 was approved only in February 2019, we tried to test the author's method for calculating the human development index to assess the level of human capital among the macro-regions of the Russian Federation. Therefore, further, having designated the methodology for calculating the HDI of macro-regions of the Russian Federation, we will analyze them and consider the general situation with the human development index in 2010-2017 among macro-regions.

\begin{tabular}{|c|c|c|c|c|c|c|c|c|}
\hline & 2010 & 2011 & 2012 & 2013 & 2014 & 2015 & 2016 & 2017 \\
\hline Angara-Yenisei & 0,419 & 0,433 & 0,454 & 0,462 & 0,471 & 0,456 & 0,459 & 0,473 \\
\hline Volgo-Kamsky & 0,444 & 0,467 & 0,502 & 0,522 & 0,533 & 0,520 & 0,527 & 0,542 \\
\hline Volgo-Uralsky & 0,452 & 0,471 & 0,507 & 0,520 & 0,534 & 0,513 & 0,516 & 0,529 \\
\hline Far Eastern & 0,373 & 0,396 & 0,421 & 0,433 & 0,438 & 0,425 & 0,429 & 0,441 \\
\hline Northern & 0,422 & 0,448 & 0,482 & 0,483 & 0,482 & 0,467 & 0,458 & 0,474 \\
\hline Northwestern & 0,534 & 0,560 & 0,638 & 0,617 & 0,630 & 0,582 & 0,613 & 0,625 \\
\hline North Caucasian & 0,380 & 0,389 & 0,421 & 0,436 & 0,447 & 0,431 & 0,433 & 0,442 \\
\hline Ural-Siberian & 0,472 & 0,495 & 0,520 & 0,534 & 0,535 & 0,518 & 0,522 & 0,543 \\
\hline Central Black Eart & 0,473 & 0,495 & 0,534 & 0,548 & 0,556 & 0,541 & 0,544 & 0,559 \\
\hline Central & 0,588 & 0,624 & 0,722 & 0,653 & 0,672 & 0,637 & 0,641 & 0,675 \\
\hline South Siberian & 0,412 & 0,428 & 0,459 & 0,467 & 0,473 & 0,449 & 0,448 & 0,469 \\
\hline Southern & 0,450 & 0,463 & 0,490 & 0,498 & 0,503 & 0,488 & 0,496 & 0,509 \\
\hline
\end{tabular}

Fig.2. Human Development Index matrix by macro-regions of the Russian Federation in 2010-2017

Further, Figure 2 shows the matrix of the weighted average HDI by types of macro-regions of the Russian Federation from 2010 to 2017. In general, across macroregions, the spread of the human development index is small: from 0.373 in the Far Eastern macro-region in 2010 to 0.722 in the Central macro-region in 2012. The maximum values of the index are expressed in financial and economic centers: from 0.533 to 0.722 - these are the Central and North-Western macro-regions. They include the city of Moscow, where the level of wages is quite high, and the city of St. Petersburg, which shows rather high indicators in terms of education. The minimum values of the indicator are observed in the Far
Eastern macro-region - from 0.373 to 0.441 from 2010 to 2017, as well as in the North Caucasus macro-region - from 0.380 to 0.442 in the same years, respectively.

The fluctuations in the human development index are more pronounced in the Volga-Kama (from 0.444 to 0.542 ), VolgaUral (from 0.452 to 0.529 ) and in the Central Black Earth (from 0.473 to 0.559 ) macro-regions. For other types of macro-regions, the weighted average values of the human development index are close to the average, which for all periods participating in the sample is 0.500 .

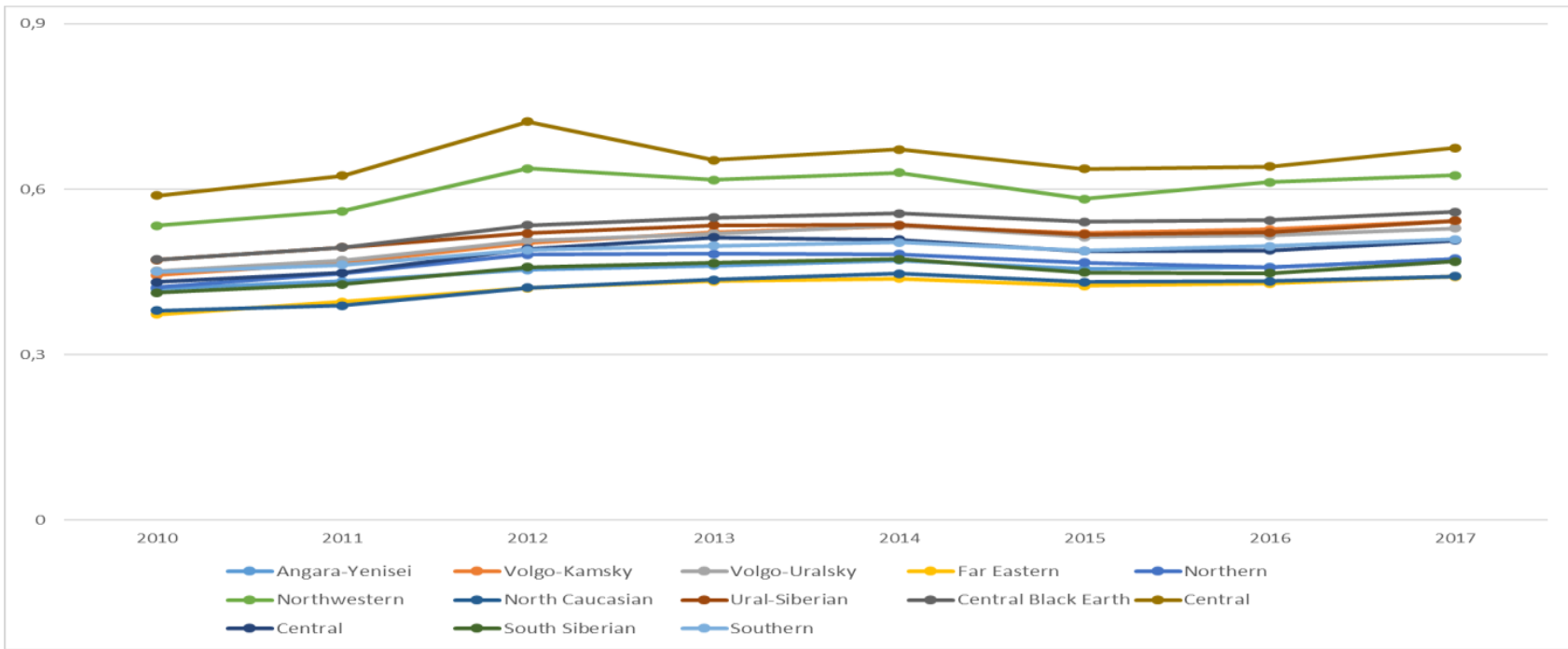

Fig.3. Dynamics of the human development index by macro-regions of the Russian Federation from 2010 to 2017 [made by the author] 
Since the beginning of 2010, the human development index of all types of macro-regions has been steadily growing, which is illustrated in Figure 3. The highest values are shown by two macro-regions - Central and Northwest. The maximum values in these macro-regions were observed only in 2012 and amounted to 0.722 in the Central and 0.638 in the North-West. At the same time, in 2015, less developed macro-regions have a tendency to an increase in the human development index.

\section{CONCLUSION}

Thus, in this article we have shown how the methodology of the UN Development Program was applied to calculate the human development index among the regions of the Russian Federation. Our next purposeful step was to improve the generally accepted UNDP methodology by adding new components to the income index, namely, we replaced GRP per capita with unemployment and wages.

We applied the new author's methodology to calculate the human development index among the regions of the Russian Federation, and the results were tested in the macro-regions of the Russian Federation, which were introduced into economic circulation by the Spatial Development Strategy until 2025.

Our study is the first step towards determining the theoretical and methodological foundations of the process of spatial development on the example of the macro-regions of the Russian Federation. This process is extremely important for solving an urgent practical task - identifying the directions of transforming the characteristics of the economic space of the country and its individual territories that are adequate to the current situation and the existing problems.

Approbation of the methodology for calculating the human development index in the macro-regions of the Russian Federation allowed us to draw the following conclusions:

- the human development index was first calculated on the example of Russian macro-regions. The calculation results allow us to see the position of macro-regions in terms of human development and identify the leading macro-regions these are the Central and Northwestern macro-regions, as well as those where the index shows values below average (Far East and North Caucasian);

- we believe that the role of indices in interregional comparison is very important, since it allows us to assess the dynamics of human development in a specific macro-region for a certain period, and also makes it possible to carry out a comparative analysis of the dynamics of the human development index to assess human capital in different regions within a particular country;

- the dynamics of the human development index among macro-regions makes it possible to pay attention to those macro-regions where large investments are needed in the development and maintenance of the level of human capital, for example, by investing in it, improving the education system, healthcare, increasing incomes of the population, establishing the institutional structure of the state, etc.;

- analysis of the dynamics of the human development index in combination with interregional comparisons and comparisons of macro-regions makes it possible to objectively assess the role of the newly approved macroregions in the development of the country's human potential;

- in our opinion, the UNDP methodology used by us, like any other generally accepted methodology for intercountry comparisons, should be adapted to the specifics of a particular country if it is applied for interregional comparisons. This makes it possible to analyze the experience of not only different countries, but also the experience of regions within the country and draw conclusions about which methods of influencing human capital are the most effective.

In conclusion we have to say that legality and expediency of practical application the main conceptual approaches set out in the Concept of the Spatial Development Strategy are to be confirmed, scientifically substantiated and comprehensively developed as part of the development of the Spatial Development Strategy of the Russian Federation.

\section{ACKNOWLEDGMENT}

The research was carried out within the framework of the grant of the President of the Russian Federation for state support of leading scientific schools of the Russian Federation, project number NSH-2600.2020.6

\section{REFERENCES}

[1] Regional development. Ministry of Economic Development of the Russian Federation, 2020. DOI: https://en.economy.gov.ru/material/activities/regional_development/

[2] On the approval of the Spatial Development Strategy until 2025, 2020. DOI: http://government.ru/docs/35733/

[3] A.N. Golovkov "Spatial development as an economic category", Management of economic systems: electronic scientific journal, 2(26), 2011, pp. 14-20. DOI: https://elibrary.ru/download/elibrary_16220935_31536996.pdf

[4] I.V. Mitrofanova, V.V. Selyutin, N.P. Ivanov "White Spots" of the Spatial Development Strategy of Russia: Discussion of the Project. Regional Economy. South of Russia, 7(1), 2019 pp. 42-55. DOI: https://doi.org/10.15688/re.volsu.2019.1.4

[5] Human Development Report 2018, Human Development for Everyone, United Nations Development Programme, 2018. DOI: http://hdr.undp.org/en/2018-update

[6] R.P. Yakunina, "Human capital as a strategic instrument of socioeconomic development of the regions of the Russian Federation.", Bulletin of Samara state economic university, 11(181), 2019, pp. 1723. https://elibrary.ru/download/elibrary_42543676_61315438.pdf

DOI:

[7] A.I. Shinkevich, S.S. Kudryavtseva., Ivanov, G.G., O.N. Korotun; I.I. Ishmuradova ; R.R. Gainullina, S.Sh. Ostanina "Research and Technological Capacity of Russia as an Indicator of Knowledge Economy Growth", International journal of advanced biotechnology and research,2017, vol 8, pp. 156-163.

[8] A.N. Dyrdonova, A.I. Shinkevich, F.F. Galimulina, T.V. Malysheva, I.A. Zaraychenko, V.I. Petrov, M.V. "Shinkevich Issues of Industrial Production Environmental Safety in Modern Economy", Ekoloji 27(106), 2018, pp. 193- 201.

[9] R.P. Yakunina, G.A. Bychkov "Correlation analysis of the components of the human development index across countries", Procedia Economics and Finance, 24, 2015, pp. 766-771. DOI: https://www.sciencedirect.com/science/article/pii/S221256711500692 9

[10] Regions of Russia. Socio-economic indicators 2017. Federal State $\begin{array}{lll}\text { Statistics } & \text { Service. } & \text { DOI: }\end{array}$ https://rosstat.gov.ru/folder/210/document/13204

[11] E Ughetto, M. Cowling \& Neil Lee. "Regional and spatial issues in the financing of small and medium-sized enterprises and new ventures", 53(5),2019, $\quad$ pp. 617-619. https://doi.org/10.1080/00343404.2019.1601174 
[12] Desmet, Klaus, and Esteban Rossi-Hansberg. Spatial Development. American Economic Review, 2014, 104 (4), 1211 p. DOI: 10.1257/aer.104.4.1211

[13] Strategies for the spatial development of the Russian Federation for the period up to 2030. DOI: http://xn----7sbbhnbqiallebd4mma.xn-p1ai/uploadedFiles/files/Kontseptsiya_SPR.pdf

[14] A.V. Suvorova "Spatial development: content and features", Journal of New Economy. 2019,20 (3), pp. 51-64. DOI: 10.29141 / 2658-5081201920-3-4

[15] E. Medeiros "Spatial Planning, Territorial Development, and Territorial Impact Assessment”, Journal of Planning Literature,2019 ,34 (2), pp. 171-182. DOI:10.1177/0885412219831375

[16] K. Spiekermann, M. Wegener, “Accessibility and Spatial Development in Europe". Scienze Regionali. 2006, 5 (2), pp. 15-46. DOI: https://www.researchgate.net/profile/Michael_Wegener3/publication/ 254415069_Accessibility_and_spatial_Development_in_Europe/links /0a85e534f91641b4c1000000.pdf 